\title{
Apoptotic effect of silver nanoparticles in rat
}

I. Ashour ${ }^{1}$; S, Saleh ${ }^{1}$; A. , Shalby ${ }^{1}$; E. Ibrahim ${ }^{2}$ and M., Dowidar ${ }^{2}$

${ }^{1}$ Biochemistry Department, Faculty of Vet. Medicine, Suez Canal University, Egypt

${ }^{2}$ Animal Health Research Institute, Agriculture Research centre, Dokki, Egypt.

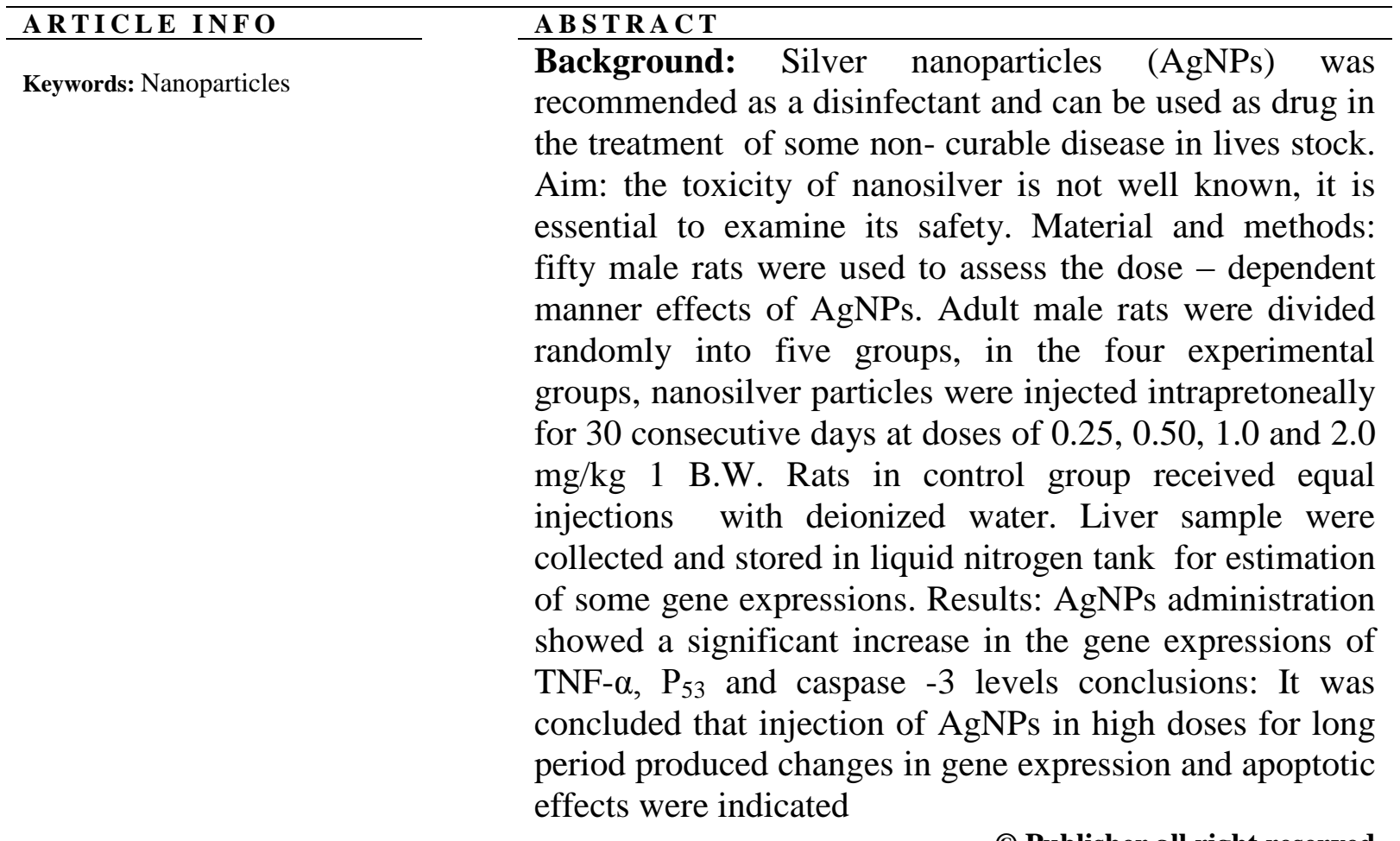

\section{Introduction:}

Nanoparticles are engineered materials produced within the nanoscale range of 1-100 $\mathrm{nm}$ in one or more dimenions, pure silver has the highest electrical and thermal conductivity of all the metals and has low contact resistance [1].

Silver nanoparticles (AgNPs) have been used in a wide variety of applications, as antimicrobial agents and have been incorporated into a number of products as industrial and food products in addition to biological and medical applications [2].
Nanosilver with a particle size less than $20 \mathrm{~nm}$ in diameter has been reported to be effective in the treatment of certain infectious diseases [3], and is effective in retarding growth of bacteria , molds and harmful spores. It has been reported that silver is reemerging as a viable treatment options for infections associated with burns, open wounds, and chronic ulcers [4].

Silver nanoporticles (AgNPs) can be ingested via water, food cosmetics, drugs and drug delivery devices [5]. Other investigators have demonstrated 
that silver ions released from ingested products into the blood and can accumulate in body organs and have toxic effect in the liver and kidney[6]; it has been reported that AgNPs are more toxic than other metal nanoparticles, but the mechanism of their toxicity is not clear [7] and [8].

The distribution of nanoparticles into major organs including liver, kidney, lung, spleen, lymph nodes and bone marrow has been reported in mice [9] and [10].

On the other hand NPs can elicit a spectrum of tissue responces such as cell activation, generation of reactive oxygen species (ROS), inflammation and cell death [11]; these studies provided evidence that the cytotoxicity of AgNPs may be partially due to their induction of cellular oxidative stress through the generation of free radicals and ROS [11], this is of clinical significance because certain pathological conditions as inflammation is associated with elevated oxidative stress and this may in turn alter the sensitivity of cells and tissues to potentially cytotoxic AgNPs increasing their market value [12].

Liver damage has been proven to be associated with redox imbalance and oxidative stress [13]. Cytotoxicity induced by Ag-NP exposure has been demonstrated in a number of studies with a variety of factors influencing observed cyto- and geno-toxic effects [14] and [15].

Nano-Genotoxicology is another new term that represent the growing trend of research into NPinduced genotoxicity and carcinogenesis [16]. Recent reports pointed that, long-term inflammation and oxidative stress present in tissue due to NPs toxicity, can eventually induces DNA damage in cells and tissues. Continuous ROS production in the cell can cause gene mutations/deletions leading to mutagenesis, carcinogenicity, and subsequently development of tumors and cancer. Particularly the metal based NPs like Ag NPs [15], Au NPs [17] and $\mathrm{TiO}_{2}$ NPs [18] are important for that kind of ROS production and genetic damage. As a result of DNA damage induced by NPs, single-strand DNA breaks, double strand breaks, DNA deletions and genomic instability in the form of increase in 8-hydroxy2deoxyguanosine levels are formed [19]. According to [20] long-term exposure of cells to NPs displayed genome instability under comet assay analysis, altered cell cycle kinetics in flow cytometry and induced protein expression of $\mathrm{p} 53$, having a critical role in responding to various stresses that cause DNA damage, and DNA repair-related proteins.

Studies showed the genotoxicity of 5 nm Ag NPs using two standard genotoxicity assays, and reported that AgNPs did not induce mutations in five different $\mathrm{S}$. typhimurium strains (TA102, TA100, TA1537, TA98 and TA1535) [21]. However, it displayed concentration-dependent geno-toxicity in the human lymphoblast TK6 cell micronucleus assay.

Despite the growing applications for products containing $\mathrm{Ag}-\mathrm{NPs}$, there is little information about potential toxicity and side effects [22]. In vitro evidence supports the suggestion that Ag-NPs induce strong cytotoxicity and proinflammatory effects [23].

Production of reactive oxygen species (ROS) and the release of cytokines are considered to be the mechanisms by which metal nanomaterials induce toxicity [24]. ROS are continually generated and eliminated in biological systems by 
endogenous or exogenous antioxidants [25] \& [26], but excessive production of ROS can lead to apoptosis and cause oxidative damage [27]. Apoptosis is initated by the sequential activation of caspases, which are a group of cysteime proteases exist in cells as inactive proengzymes [28]. Caspase -3 is a key effector caspase involved in the apoptotic cascade within cells, cleaving different cellular substrates and inducing apoptotic cell death[29].

The aim of this work was the study the effect of several doses and prolonged exposure to silver nanoparticles in rats.

\section{MATERIAL AND METHODS}

\subsection{MATERIAL}

\subsubsection{Chemical}

Silver dispersionnanoporticles , $20 \mathrm{~nm}$ particles size, $0.04 \mathrm{mg} / \mathrm{ml}$ in aqueous buffer, contain sodium citrate as stabilizer was obtained from sigma - Aldrich Co.

\subsubsection{Experimental animals:}

Fifty (50) male adult albino rats (200-250g), obtained from National Research Centre, Dokki, Egypt were used in this study. Animals were housed in groups of ten in cages at $25+0.5^{\circ} \mathrm{C}$, under 12 : $12 \mathrm{hrs}$ light / dark cycle, and $12 \mathrm{hr}$ free access to water and food. Animals from all groups were kept under similar environmental conditions of temperature, illumination ventilation, and received the determined diet during the course of the experiment. Food and water were kept in special open containers fixed in the wall of the cages. Cleaning and changing food and water was done for all animals twice daily . The experimental protocols were approved by the Faculty of Vet. Medicine, Suez Canal University, Ismailia, Egypt. These are no restrictions in Egypt for the use of experimental animals for
Laboratory studies. Animals of this study were cared for in accordance with the principles outlined in the guide for the care and use of laboratory animal issued by the animal care Committee of National Veterinary Research and Quarantine service (NVRQS).

\subsubsection{Experimental design:}

The experimental albino rats were divided into five groups, each group comprising of ten rats, after adaptation in the animal houses in Faulty of Vet. Medicine Suez Cana University for one week. The groups named as N1, 2, 3, 4 and 5. Group N1, was called control group and was gives deionized water IP and the other four groups , N2 to 5 were called experimental or treated groups. Silver nanoparticles was administered intra peritoneal for 30 days at doses of 0.25 , $0.5,1.0$ and $2.0 \mathrm{mg} / \mathrm{kg}$. / B.W. of rat according to protocol of [30].

\subsection{METHODS}

\subsubsection{Sampling:}

The rats were dissected ; liver organs were separated carefully and washed with saline solution. After that, part of liver organs were stored in liquid nitrogen tank for genes expressions study.

\section{Molecular determinations}

- Determination of P53 and Casapase-3 enzyme and TNF- $\alpha$ gene expression using a semiquantitative RT-PCR [31].

1. Primers sequences and preparation

Primer sequences of rat TNF- $\alpha$, P53, caspase-3 and $B$-actin were obtained from the published sequences of [24] and for GRD from [32]. And listed below in table A. 
Primers Preparation according to the manufacture instructions; Primers were prepared as follow:

1. Lyophilized primer at $-20 \mathrm{C}^{\mathrm{O}}$ was equilibrated at room temperature and spin down for 3 sec. using vortex.

2. Lyophilized primer was diluted (both forward and reverse with Rnase free water (the volume was added to get $100 \mu \mathrm{M}$ stock) and then the tube was gently invert for $2 \mathrm{~min}$ at room temperature.

3. Stock primer was diluted with RNase free water (PH 8.0) to get 5 $\mu \mathrm{M}$ and kept at $-20 \mathrm{C}^{\mathrm{O}}$ until used.

\section{Statistical calculation:}

The obtained data were analyzed and graphically represented using the statistical package for social science (SPSS, 15.0 software 2009) for obtaining mean and standard deviation and error. The data were analyzed using one way ANOVA to determine the statistical significance of differences among groups. Duncan's test were used for making a multiple comparison among the groups for testing the inter grouping homogenesity.

\section{Results}

Results in Table (1) and Figure (1) showed that there was a significant increase in the gene expression of P53 within the increase of silver nanoparticles conc.

Results in Table (2) and Figure (2) showed that there was a significant increase in the gene expression of TNF- $\alpha$ within the increase of silver nanoparticles conc.

Results in Table (3) and Figure (3) showed that there was a significant increase in the gene expression of
Casapase-3 within the increase of silver nanoparticles conc.

\section{DISCUSSION}

At the present study we tried to identify the adverse effects of silver nanoparticles using rats treated with intra-peretoneal administration. In addition, we tried to investigate the effects of toxicity in the different doses of silver nanoparticles.

In this study, Tables (1-3) and Figs. (1-3), it was established that exposure to Ag-NP resulted in significant transcription of inflammatory cytokines and tumour mecrosis factor (TNF)- $\alpha$. Ag-Np exposure can generate intracellular reactive oxygen species (ROS) in mammalian cells, with excessive production linked to cell damage and initiation of an inflammatory response [33] and [34]. Oxidative stress in monocytes coupled with the release of inflammatory cytokines is a natural protective response, however, this process can become pathogenic when normal cell control systems are over whelmed. Evidence has indicated a correlation between ROS production and inflammation resulting in an amplified response. Oxidative stress causes expression of cytokines and TNF- $\alpha$ which in turn contribute to ROS generation. This produces an amplification loop between oxidative stress and inflammation initiated by Ag-Np exposure [35]. This loop while potentially contributing to resolution may also cause continued proinflammatory cytokine induction past the threshold of resolution thus inducing a continued inflammatory response and toxicity [36]; [37] and [38].

In vitro studies support cell toxicity for Ag-NPs [39], which can induce oxidative stress in human hepatoma 
cell [27], DNA damage in testicular cells [40], reduced cell viability in alveolar macrophages and lung epithelial cells (Soto, et al., 2007), and apoptosis in Hola cells [11]. The cyotoxic effects of Ag-NPs have been reported in various cancer cell lines [41] and [42]. Most administered nanoparticulate silver has been described to be deposited in the liver, the major organ of detoxification [43].

This study revealed that administration of Ag-NPs for 30 days likely led to early apoptotic stages, we observed that administration of $\mathrm{Ag}$-NPs induced upergulation of caspase -3. Caspase-3 as an effector caspase, deals with the intrinsic pathway of apoptosis [17]. Eckle, et al., have shown that expression of caspase- 3 represents a reliable marker of apoptosis in the rat liver [28].

Ag-NPs exposure increased apoptosis, as demonstrated by increase in $\mathrm{P}_{53}, \mathrm{P}_{21}$ and capases 3,8 and 9. AG-NPs caused DNA damage and reduced the interaction between $\mathrm{P}_{53}$ and NF-kB [44].

Since silver nanoparticles (AgNPs) possess unique cytotoxic features, we examined, whether their activity could be exploited to kill tumour suppressor deficient cancer cells. This found that both sized AgNPs $(5$ and $35 \mathrm{~nm})$ targeted mitochondria and induced apoptosis in wild- type $\mathrm{P}_{35}$ containing V20s and $\mathrm{P}_{53}$-deficient Saos-2 cells. Ag-NPs are able to kill osteosarcoma cells independently from their actual $\mathrm{P}_{53}$ status and induce $\mathrm{P}_{53}$ independent cancer cell apoptosis [45]. Although many studies have reported the apoptotic effects exhibited by silver nanoparticles (Ag-NPs) in various circumstances, the apoptosis mechanisms of AG-NPs is unclear. As a result, Ag-NPs -significantly enhanced DNA fragmentation dose dependently and treatment with $\mathrm{P}_{53}$ siRNA or pifithrin- $\alpha$ prevented DNA fragmentation. They also found that apoptosis-related genes (Caspase-3, Bax, and Bcl-2) were regulated by Ag-NPs , which was detected by mRNA and protein level; these results suggest that Ag-NPs induced $\mathrm{P}_{53^{-}}$ mediated apoptosis in BEAS-2B cells [46].

\section{CONCLUSION}

From these study, it was concluded that the intrapretoneal injection of silver nanoparticles produced changes, gene expressions, of TNF- $\alpha$, P53 and capase- 3 in the liver tissues and apoptotic effects were indicated. Generally, results of this study confirmed the toxicity of silver nanoparticles.

\section{REFERANCES:}

1. Osama, M.M.S. and Rehab, M.H. (2014): Effects of intraperitoneally injected silver nanoparticles in histological structures and blood parameters in the albino rat. Int $\mathrm{J}$. Nanomedicine, 9 : 1505-1517.

2. Maneewattanapinyo, P; Banlunara, W.; Thammacharoen, $\quad$ C.; Ekgasit, S. and Kaewamatawong, K. (2011): An evaluation of acute toxicity of colloidal silver nanoparticles. J. Vet. Med. Sci., $73: 1417-1423$.

3. Tiwari , D.K.; Jin, T. and Behari , J. (2011): Dose dependent in vivo toxicity assessment of silver nanoparticles in wistar rats. Toxicol Mech Methods, 21 : 13-24.

4. Atiyeh, B.S.; Costagliola, M.; Hayek, S.N. and Dipo,S.A. (2007): Effect of silver on burn 
wound infection control and healing. Burns, 33 : 139-148.

5. Sardari, R.R.; Zarchi, S.R.; Talebi, A. et al. (2012): Toxicological effects of silver nanoparticles in rats. Afr J. Microbiol Ros, 6 5587-5593.

6. Park, E. and Bae, E. (2010): Repeated - dose toxicity and inflammatory responses in mice by oral administration of silver nanoparticles. Environ. Toxicol. Pharm, 30 : 162-168.

7. Braydich-Stolle, L.; Hussain, S.; Schlager, J.J. and Hofman, M.C. (2005): In vitro cytotoxicity of nanoparticles in mammalian germline stem cells. Toxicol. Sci., 88:412419.

8. Tang, J. (2008): Status of biological evaluation on silver nano-particles. J. Biomed Eng., 25 : 958-961.

9. Martin, O. and Gary, $H$. (2008): The effect of nanoparticle exposure on male reproduction fanction. Nanotoxicology, 10 : 22612268.

10. Lagaron, J.M.; Cabedo, L.; Cava, D. et al., (2005): Nano technology and improving packaged food quality and safety . Food Addit Contam, 22 , 994-998.

11. Miura, N. and Shinohara, Y. (2009): Cytotoxic effect and apoptosis induction by silver nanoparticles in hela cells. Biochem. Biophys. Res. Commum., 390 (3): 733-737.

12. Korani, M.; Rezayat, S.; Glani, K.;Bidgoli , S.A. and Adeli, S. (2007): Acute and subchronic dermal toxicity of nanosilver in guinea pig . Int. J. Nanomed., 6: 855-862.
13. Wu, D. and Cederbaum, A. I. (2009): Oxidative stress and alcoholic liver disease. Seminars in liver disease. Theime Medical Publishers.

14. Kim, S.; Cho, J.E.; Choi, J.; Chung, K. H.; Park, K. Y. J. And Ryu, D. Y. (2009): Oxidative stress- dependent toxicity of silver nanoparticles in human hepatoma cells. Toxicol. In vitro , 23 : 10761084.

15. Choi, J. E.; Kim, S.; Ahn, J.H.; Youn, P. ; Kang, J.S.; Park, K. and et al. (2010): Induction of oxidative stress and apoptosis by silver nanoparticles in the liver of adult zebrafish. Aquat. Toxicol. $100: 151-159$

16. Arora S, Jain J, Rajwade JM and Paknikar KM. (2008): Cellular Responses Induced by Silver Nanoparticles: in Vitro Studies. Toxicology Letters; 179:93-100.

17. Lee, T.Y.; Liu, M.S.; Huang, L.J.; Lue, S.I. and Lin , L.C. et al. (2013): Bioenergetics failure correlated with autophagy and apoptosis in rat liver following silver nanoparticles intrperiteneal administration. Particle Fib. Toxicol., 10 (40): 1-13.

18. Hu RP, Zheng L, Zhang T, Cui YL, Gao GD, Cheng Z, Chen J, Tang M, Hong FS. (2011): Molecular Mechanism of Hippocampal Apoptosis of Mice Following Exposure to Titanium Dioxide Nanoparticles. Journal of Hazardous Materials; 191:3240.

19. Song MF, Li YS, Kasai H., Kawai K. (2012): Metal Nanoparticle-Induced Micronuclei and Oxidative 
DNA Damage in Mice. Journal of Clinical Biochemistry and Nutrition; 50(3):211-216.

20. Mroz RM, Schins RP, Li H, Jimenez LA, Drost EM, Holownia A, MacNee W, Donaldson K. (2008): Nanoparticle-driven DNA Damage Mimics Irradiationrelated Carcinogenesis Pathways. European Respiratory Journal; 31:24151.

21. Li, F.; Weir , M.D. ; Chen, J. and $\mathrm{Xu}$, H.H. (2013): Comparison of quaternary ammonium- containing with nano-silver containing adhesive in antibacterial properties and cytotoxicity. Dent. Mater ., 29 (4): 450-461.

22. Hussain, S.M. ; Hess, K.L.; Gerhart, J.M. ; Geiss, K. T. and Schlager , J.J. (2005): In vitro toxicity of nanoparticles in BRL-3A rat liveer cells. Toxicol. In vitro., 19 (7) : 97583.

23. Dziendzikowska, K.; Gromadzaka- Ostrowska, J.; Lankoff, A.; Oczkowski, M. Krawczynska, A.; Chwastowska, J. et al. (2012): Time - $\quad$ dependent biodistribution and excretion of silver nanoparticles in male wistar rats. J. Appl. Toxicol. , 32 (11) : 920-8.

24. Xu F, Fok TF, Yung E, Yin JA, To KF. (2000): Antioxidant enzyme activities and antioxidant enzyme gene expression in hyperoxia induced lung injury in premature rat. HK J Paediatr 5:3-7

25. Mohammadi,

A.; Bazrafshani, M.R. and Oshaghi, E.A.(2013): Effect of garlic extract on some serum biochemical parameters and expression of npc111 , abca1, abcg5 and abcg8 genes in the intestina

of hypercholesterolemic mice. Indian J. Biochem. Biophys, 50 (6): 500-4.

26. Piao, M. J.; Kang, K.A.; Lee, L. K.; Kim, H.S.; Kim, S. Chol, J. Y, et al. (2011): Silver nanoparticles induce oxidative cell damage in human liver cells through inhibition of reduced glutatholine and induction of mitochondraia involved apoptosis . Toxicol Let, 20 91): 92-100.

27. Xu, L, Li, X.; Takermura T.; Hanagata N.; Wu G. and Chou LL. (2012): Genotoxicity and molecular response of silver Nanoparticle (NP) based hydrogel. J. Nanbiotechnology , 2012: 10: 16.

28. Eckle, V.S.; Buchmann, A.; Bursch, W., et al. (2004): Immunohistochemical detection of activated caspases in apoptotic hepatocytes in rat liver. Toxicol. Pathol., 32 (1): 9-15.

29. Bantel, H.; Ruck, P.; Gregor, M.; Schulze - Osthoff K. (2001): Detection of elevated caspase activation and early apoptosis in liver diseases. Eur. J. Cell Biol. , 80 (3): 2309-9.

30. Roshan, R.A.S.; Saeid, R.Z. ; Alireza, T.; Sima, N.; Saber, I. and et al. (2012): Toxological effects of silver nanoparticles in rats. African Journal of Microbiology Research, Vol. 6 (27) , pp. 5587-5593.

31. Meadus W.J. (2003): A semiQuantitative RT-PCR method to measure the in vivo effect of dietary conjugated linoleic acid on protein muscle PPAR gene 
expression. Biol. Proced. On line 5 (1): 20-28.

32. Olga B, Sergueï $S$, Véronique L, Jean MF, Saúl V. (2010): Transl an approach to the study of gene expression in hepatocarcinogenesis initiation. Oncol 3(2):142-148

33. Asharani, P. V.; Mun, G. I. K.; Hande, M. P. and Valiyaveettil, S. (2009): Cytotoxicity and genotoxicity of silver nanoparticles in human cells. ACS nano, vol. 3, No 2, pp. 279-290.

34. Lim,D. H.; Jang, J.; Kim, S.; Kang, T.; Lee , K. and Cohi, I. H. (2012): The effects of sub- lethal concentrations of silver nanoparticles on inflammatory and stress genes in human macrophages using cDNA microarray analysis. Biomaterials , 33 : 4690-99.

35. Kim, S. and Ryu, D. Y. (2013): Silver nanoparticles induced oxidative stress, genotoxicity and apoptosis in cultures cell and animal tissue. J. Appl. Toxicol. 33 : 78-89.

36. Lander, H. M. (1997): An essential role for free radicals and derived species in signal transduction . FASTB J. 11 : 118-124.

37. Acker, H. (2005): The oxygen sensing signal cascade under the influence of reactive oxygen species. Philos. Trans. R. Soc. Land, B. Biol. Sci. 360: 2201-10.

38. Franco, R.; Sanchez. Olea, R.; Reyes- Reyes, E.M. and Panayiotidis, M.L. (2009): Environmental toxicity, oxidative stress and apoptosis : menage a trios. Muat. Res. 674: 3-32.
39. Munger, M. A.; Radwanski, P.; Hadlock, G.C.; Stoddard, G. et al. (2014): In vivo human time - exposure study of orally dosed commercial silver nanoparticles. Nanomedicine ; 10 (1) : 1-9.

40. Asare , N.; Instances , C.; Sandberg, W. J.; Refsnes , M.; Schwarze, P. Kruszewski M. et al. (2012): Cytotoxic and genotoxic effects of silver nanoparticles in testicular cells. Toxicology , 291 (1-3) : 65-72.

41. Park, E.J. ; Bae, E.; Yi, J.; Kim, Y.; Choi, R.; Lee, S.H. et al. (2010): Repeated-dose toxicity and inflammatory responses in mice by oral administration of silver nanparticles. Environ. Toxicol. Pharmacol., 30 (2): 132-138.

42. Ciftci , H.; Turk, M.; Tamer , U.; Karahan , S.; Menemen, Y.(2013): Silver nanoparticles: cytotoxic apoptotic and necrotic effects on MCF-7 cells. Turk J. Biol. 37 (5): 57381.

43. Xue, Y.; Zhang, S.; Huang, Y.; Zhang, T.; Liu , X.; Hu, Y. et al. (2012): Acute toxic effects and gender - related biokinetics of silver nanoparticles following an intravenous injection in mice . J. Appl. Toxicol. , 32 (11): 8909.

44. Shakti, R. S.; Purusottam, M.; Ranjan, P.; Dipon, D. et al. (2013) : Silver-based nanoparticles induce apoptosis in human colon cancer cell mediated through P53. Nanomedicine, Vol. 8, No. 3, Pages 1307-1322.

45. David, K.; Nora, I. Csilla, K. and Monika, K. (2016): Silver nanopartyicles defeat p53 positive and p53- negative 
osteosarcoma cells by triggering mitochondrial stress and apoptosis. J. Scientific Reports, $6: 27902$.

46. Kim, H.R.; Shin, D. Y.; Park, Y. J.; Park, C.W. ; Oh, S.M. and Chung , K. H. (2014): Silver nanoparticles induce p53 - mediated apoptosis in human bronchial epithelial (BEAS-2B) cells. J. Toxicol. Sci., 39 (3): 401-12.

Table (B): Primers used in determination of the gene expression of the selected genes:

\begin{tabular}{|c|c|c|}
\hline Gene & Primers & $\begin{array}{l}\text { Product } \\
\text { length }(\text { bp })\end{array}$ \\
\hline \multirow[t]{2}{*}{ p53 } & F: 5'TCATCTTGGGCCTGTGTTATCT-3’ & \multirow[t]{2}{*}{332} \\
\hline & R: 5'GTGCAGGGTGGCAAGTGG-3' & \\
\hline \multirow[t]{2}{*}{ Caspase-3 } & F: GCAGCAGCCTCAAATTGTTGACTA & \multirow[t]{2}{*}{141} \\
\hline & R: TGCTCCGGCTCAAACCATC & \\
\hline \multirow[t]{2}{*}{$\mathrm{TNF}-\alpha$} & F 5'-ATGGGGACAATACACAAGGC-3' & \multirow[t]{2}{*}{421} \\
\hline & R 5'-TCATCTTGTTTCTCGTGGAC-3' & \\
\hline \multirow[t]{2}{*}{$\beta$-actin } & F 5'-TCACTATCGGCAATGTGCGG-3' & \multirow[t]{2}{*}{260} \\
\hline & R 5'-GCTCAGGAGGAGCAATGATG-3' & \\
\hline
\end{tabular}

Table (1): Data analysis of mRNA expression of hepatic $P^{53}$ gene in different groups:

\begin{tabular}{|c|c|c|c|c|c|}
\hline Groups & $\begin{array}{l}\text { CT of } \\
\text { target } \\
\text { gene }\end{array}$ & $\begin{array}{l}\text { CT of } \\
\text { housekeeping } \\
\text { gene }\end{array}$ & $\Delta \mathrm{CT}$ & $\begin{array}{l}\Delta \Delta \mathrm{C} \\
\mathrm{T}\end{array}$ & $\begin{array}{l}\text { Fold change } \\
=2^{-\Delta \Delta C T} \\
\text { (Means } \pm \text { S.E) }\end{array}$ \\
\hline $\begin{array}{l}\text { G1 Normal } \\
\text { control }\end{array}$ & 23.3 & 28.4 & -5.1 & 0 & $1 \pm 0.02^{c}$ \\
\hline G2 & 22.5 & 28.65 & -6.14 & $\begin{array}{l}- \\
1.044\end{array}$ & $1.09 \pm 0.08^{\mathrm{bc}}$ \\
\hline G3 & 22.71 & 28.91 & -6.195 & 1.095 & $1.2 \pm 0.03^{b}$ \\
\hline G4 & 22.987 & 29.2 & -6.213 & 1.113 & $1.24 \pm 0.06^{\mathrm{b}}$ \\
\hline G5 & 21.6 & 27.9 & -6.3 & 1.2 & $1.45 \pm 0.07^{\mathrm{a}}$ \\
\hline
\end{tabular}

Means $\pm \mathrm{SE}$ in the fold change column carrying different superscripts are significantly different at $(P \leq 0.05)$ 
Table (2): Data analysis results of mRNA expression of hepatic TNF- $\alpha$ gene in different groups

\begin{tabular}{|c|c|c|c|c|c|}
\hline Groups & $\begin{array}{l}\text { CT of } \\
\text { target } \\
\text { gene }\end{array}$ & $\begin{array}{l}\text { CT of } \\
\text { housekeeping } \\
\text { gene }\end{array}$ & $\Delta \mathrm{CT}$ & $\begin{array}{l}\Delta \Delta \mathrm{C} \\
\mathrm{T}\end{array}$ & $\begin{array}{l}\text { Fold change } \\
=2^{-\Delta \Delta C T} \\
\text { (Means } \pm \text { S.E) }\end{array}$ \\
\hline $\begin{array}{l}\text { G1 Normal } \\
\text { control }\end{array}$ & 24.6 & 28.4 & -3.8 & 0 & $1 \pm 0.01^{\mathrm{d}}$ \\
\hline G2 & 23.831 & 28.65 & -4.819 & -1.019 & $1.04 \pm 0.06^{\mathrm{c}}$ \\
\hline G3 & 24.02 & 28.91 & -4.8864 & $\begin{array}{l}1.086 \\
4\end{array}$ & $1.18 \pm 0.02^{\mathrm{b}}$ \\
\hline G4 & 24.26 & 29.2 & -4.94 & 1.14 & $1.31 \pm 0.08^{\mathrm{a}}$ \\
\hline G5 & 22.93 & 27.9 & -4.97 & 1.17 & $1.37 \pm 0.04^{\mathrm{a}}$ \\
\hline
\end{tabular}

Means \pm S.E in the fold change column carrying different superscripts are significantly different at $(P \leq 0.05)$

Table (3): Data analysis results of mRNA expression of hepatic Casapase-3 gene in different groups

\begin{tabular}{|l|l|l|l|l|l|}
\hline Groups & $\begin{array}{l}\text { CT of } \\
\text { target } \\
\text { gene }\end{array}$ & $\begin{array}{l}\text { CT of } \\
\text { housekeeping } \\
\text { gene }\end{array}$ & $\Delta$ CT & $\Delta \Delta$ CT & $\begin{array}{l}\text { Fold change } \\
=2^{-\Delta \Delta C T} \\
(\text { Means } \pm \text { S.E })\end{array}$ \\
\hline $\begin{array}{l}\text { G1 Normal } \\
\text { control }\end{array}$ & 25.6 & 28.4 & -2.8 & 0 & $1 \pm 0.08^{\mathrm{a}}$ \\
\hline G2 & 24.798 & 28.65 & -3.852 & -1.052 & $1.107 \pm 0.12^{\mathrm{a}}$ \\
\hline G3 & 25.015 & 28.91 & -3.895 & 1.095 & $1.2 \pm 0.06^{\mathrm{c}}$ \\
\hline G4 & 25.243 & 29.2 & -3.957 & 1.157 & $1.34 \pm 0.09^{\mathrm{e}}$ \\
\hline G5 & 23.876 & 27.9 & -4.024 & 1.22 & $1.5 \pm 0.07^{\mathrm{b}}$ \\
\hline
\end{tabular}

- Means S.E in the fold change column carrying different superscripts are significantly different at $(P \leq 0.05)$. 


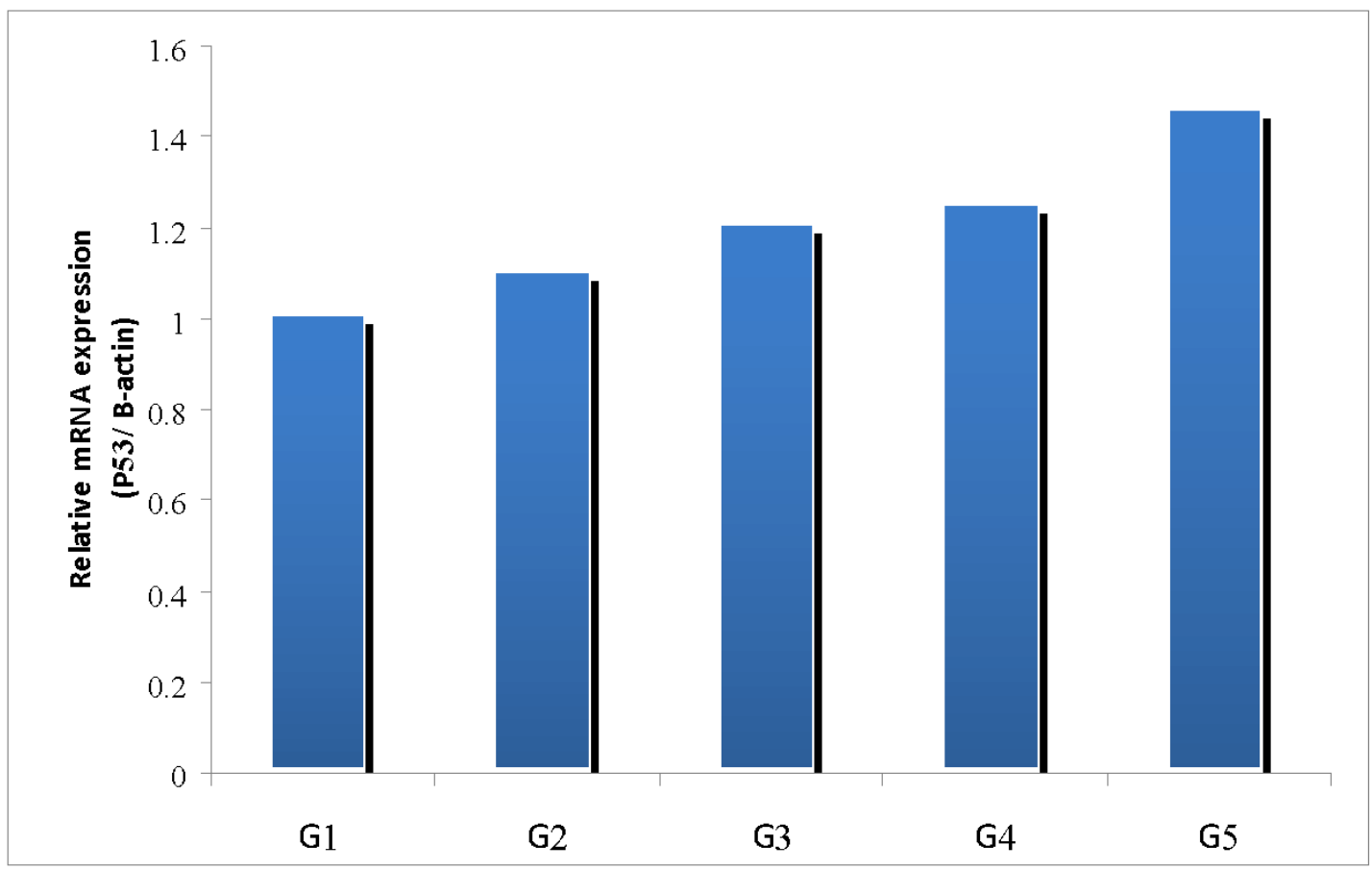

Figure (1): Fold change of $P^{53}$ gene in relation to $\beta$-actin gene

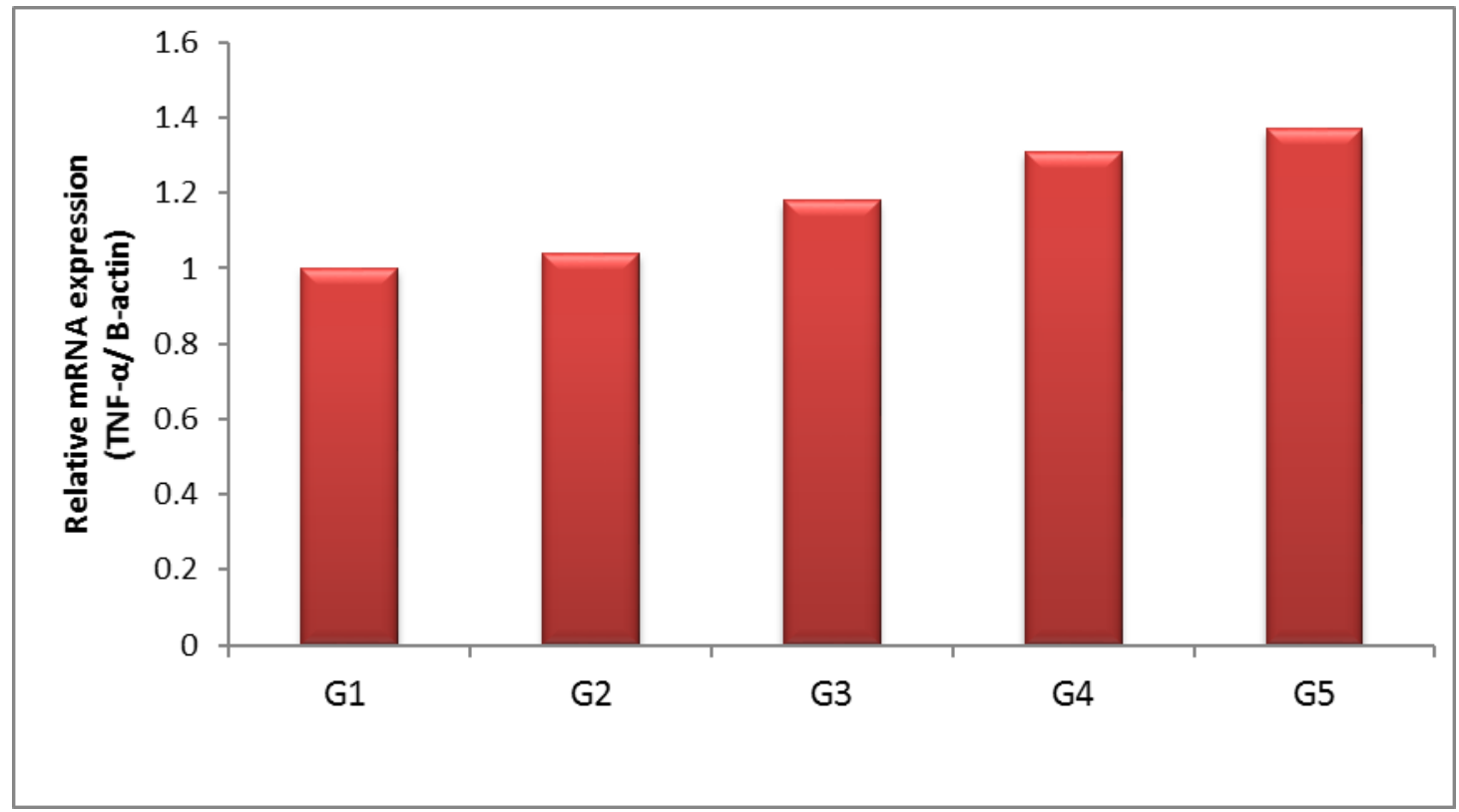

Figure (2): Fold change of TNF- $\alpha$ gene in relation to $\beta$-actin gene. 


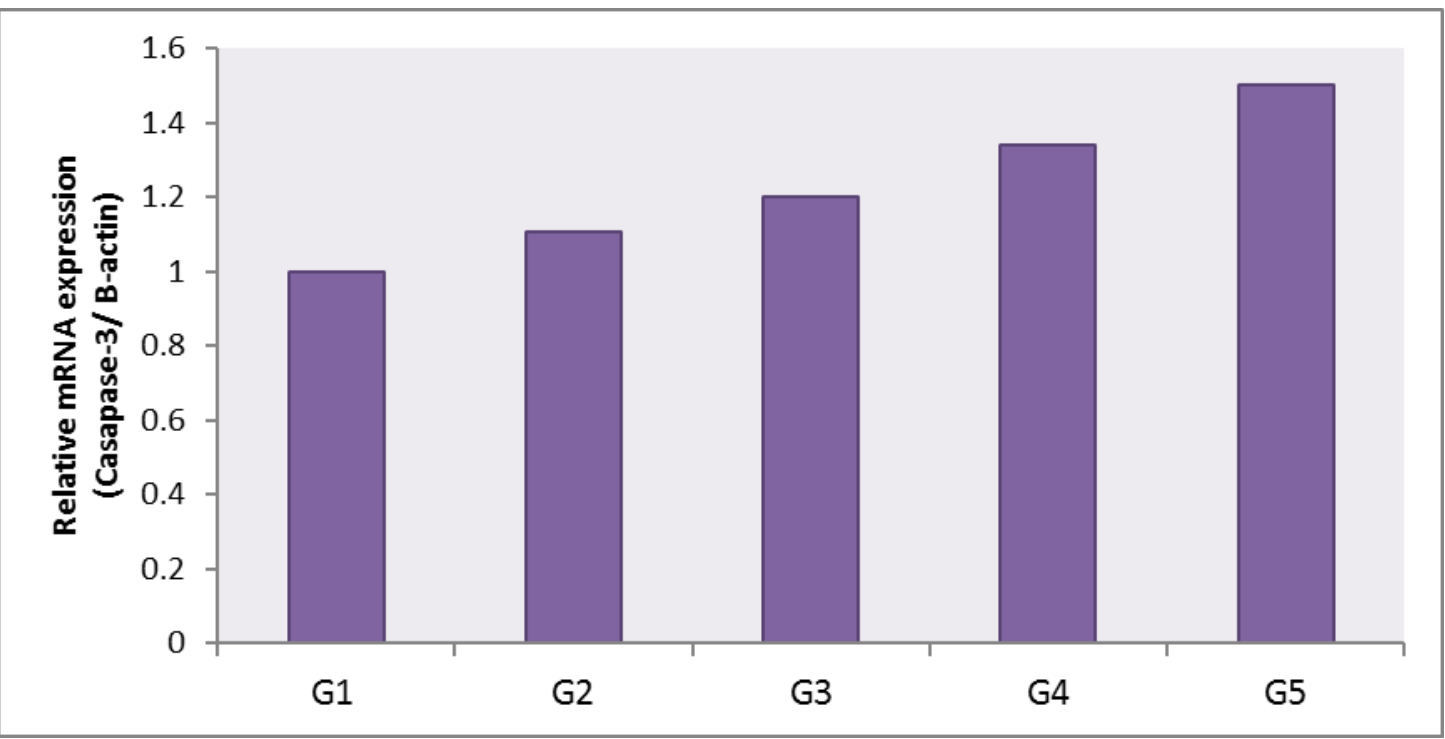

Figure (3): Fold change of Casapase-3gene in relation to $\beta$-actin gene 